\title{
Profilometria laserowa w badaniach kamiennych elementów budowlanych poddanych obróbce mechanicznej i termicznej
}

\author{
Marek Rembiśn ${ }^{1}$, Maria Kośla ${ }^{1}$
}

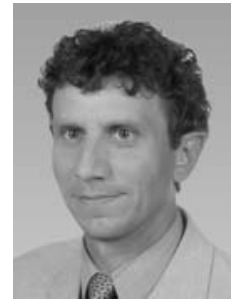

M. Rembiś

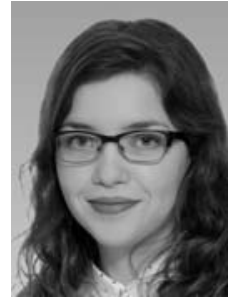

M. Kośla

Application of laser profilometry in the investigation of mechanically and thermally treated stone elements. Prz. Geol., 69: 120-126; doi: 10.7306/2021.7

A b s tr a c t. The investigation was carried out on stone slabs sawn and flamed from three commercial types of igneous rocks: the "Sunny Desert" granite, "Twilight" basalt and "Imperial Red" granite. With the following method of laser profilometry, 510 surface profiles were recorded, each of them containing 1280 measuring points. The parameters of roughness and waviness were calculated for each stone surface with a horizontal measurement accuracy of $1 \mathrm{~mm}$ and a vertical one of $10 \mathrm{~mm}$. The data of laser profiling were correlated with petrographic observations in order to identify the rock components that are most exposed to damage while preparing the stone slabs. The results indicate that the thermally treated slabs have their surface roughness distinctly higher and their waviness higher even several times than the slabs obtained by sawing. Among the three flamed slabs, the highest roughness is revealed by the medium-crystalline "Sunny Desert" granite, while in case of the cut ones - by the unequally crystalline "Imperial Red" granite. The waviness of the surfaces obtained by slab cutting and flaming is comparable in both investigated granite types. The "Twilight" basalt, which shows the porphyritic-aphanitic texture and the directional arrangement of its mineral components, reveals the lowest values of all the parameters analysed.

Keywords: laser profilometry, granite and basalt slabs, saw cut finish, flamed finish, surface roughness, surface waviness

Profilometria laserowa jest metodą pozyskiwania informacji o geometrii powierzchni różnych obiektów za pomocą skanowania ich promieniem lasera. Wykorzystuje się ją głównie do charakteryzowania struktury geometrycznej obrobionych powierzchni inżynierskich, np. stali, jednak może być także narzędziem do pomiaru nierówności powierzchni kamiennych elementów budowlanych, które są poddawane obróbce fakturalnej.

Do oceny nierówności powierzchni stosuje się pojęcia chropowatości i falistości, zdefiniowane w normach PN-58/M-04252, PN-89/M-04256/04 i PN-EN ISO 1302:2004. Różnica pomiędzy chropowatością a falistością polega na innym stosunku odległości między sąsiadującymi wierzchołkami nierówności powierzchni $(s)$ do ich wysokości (h). Chropowatość jest to zbiór nierówności o względnie małych odległościach między wierzchołkami powierzchni, tzn. s/h < 50 (PN-89/M-04256/04). Zazwyczaj jest ona oceniana $\mathrm{w}$ trakcie obserwacji pod mikroskopem. Natomiast falistość oznacza występowanie na powierzchni rzeczywistej nierówności o rozmieszczeniu przypadkowym lub zbliżonym do postaci okresowej w odstępach znacznie większych niż określone dla chropowatości, tj. $50<\mathrm{s} / \mathrm{h}<1000$ (PN-89/M-04256/04). Falistość powierzchni jest widoczna w skali makroskopowej.

Rozwój laserowych metod badawczych sprawia, że rozdzielczość pomiarów staje się coraz większa i umożliwia precyzyjne sparametryzowanie mikrogeometrii badanych powierzchni. Profilometria laserowa może zastapić dotychczas stosowaną wizualną ocenę powierzchni próbki materiału budowlanego, której wynik w znacznym stopniu jest uzależniony od subiektywnych odczuć obserwatora.

$\mathrm{Z}$ zastosowaniem profilometrii laserowej oceniono zmienność wartości parametrów chropowatości: $R a, R c$, $R t$ i Rsm oraz falistości: $W a, W c, W t$ i $W s m$ (zdefiniowa- nych w normie PN-EN ISO 4287:1999) powierzchni trzech płyt kamiennych wykonanych ze skał magmowych. Parametry te nie są wprawdzie dedykowane do charakteryzowania naturalnych powierzchni podzielności skał, jednak nadają się do opisu obrobionych elementów kamiennych, zróżnicowanych pod względem rodzaju nadanej im faktury kamieniarskiej (Tantussi, Lanzetta, 2007). Zmienność uzyskanych wyników przeanalizowano w odniesieniu do sposobu obróbki kamienia oraz jego cech petrograficznych, takich jak: tekstura, struktura oraz skład mineralny, a także podatności na obróbkę.

\section{METODYKA BADAŃ}

Do badań wybrano zróżnicowane litologicznie skały magmowe, które są powszechnie stosowane w budownictwie: dwie odmiany granitu o komercyjnych nazwach: Sunny Desert i Imperial Red oraz bazalt Twilight. Granit Sunny Desert oraz bazalt Twilight pochodzą z południowo-wschodnich Chin, z rejonu Shijing w prowincji Fujian (Zhao i in., 2015), natomiast granit Imperial Red jest eksploatowany w Indiach, w okolicach miasta Bangalore w stanie Karnataka (Ningappa i in., 2008). Materiał badawczy stanowiły płyty kamienne wykonane z tych skał, pozyskane w zakładzie kamieniarskim Kambud z siedzibą w Bochni. Jednej powierzchni każdej z tych trzech płyt nadano fakturę przecinana, uzyskaną w wyniku przecięcia piłą, a drugiej powierzchni - fakturę płomieniowana, wytworzoną w efekcie wysokotemperaturowej obróbki termicznej. Zabieg płomieniowania prowadzono w temperaturze $1280-1360^{\circ}$, w celu wygenerowania w płycie naprężeń termicznych powodujących odpryskiwanie i wykruszanie fragmentów kamienia (Kalinowski, 2003).

\footnotetext{
${ }^{1}$ AGH Akademia Górniczo-Hutnicza, Wydział Geologii, Geofizyki i Ochrony Środowiska, al. A. Mickiewicza 30, 30-059 Kraków; rembis@agh.edu.pl;kosla@agh.edu.pl
} 
Siła naprężeń powstających pod wpływem płomieniowania jest zależna głównie od wartości współczynnika cieplnej rozszerzalności objętościowej minerałów, ich właściwości sprężystych oraz gradientu działającej temperatury. Spośród minerałów skałotwórczych badanych skał najbardziej wrażliwy na zmiany termiczne jest kwarc, o współczynniku cieplnej rozszerzalności objętościowej $4,98 \cdot 10^{-5} \mathrm{~K}^{-1}$, natomiast najbardziej odporny na te zmiany jest anortyt, o współczynniku 1,51 $\cdot 10^{-5} \mathrm{~K}^{-1}$ (Robertson, 1988; Huotari, Kukkonen, 2004).

Określono skład petrograficzny badanych skał oraz wygląd ich obrobionych fakturalnie powierzchni, wykorzystując do tego celu stereoskopowy mikroskop cyfrowy Eakins, wyposażony w cyfrową kamerę o rozdzielczości 37 mln pikseli i zakresie powiększeń 10-200x.

Fragmenty dwóch powierzchni każdej z trzech płyt, czyli 6 próbek skał (o polu nie przekraczającym $100 \mathrm{~cm}^{2}$ ), zeskanowano przy użyciu skanera laserowego profilu 2D/3D ScanCONTROL firmy Micro-Epsilon. Skaner ten składa się z nieruchomej głowicy lasera o niebieskim świetle, umieszczonej nad prowadnicą, wzdłuż której jest przesuwana próbka (z zadaną stałą prędkością). Urządzenie to wykorzystuje zasadę triangulacji laserowej do dwuwymiarowego określania profilu. Generuje linię laserową na powierzchni badanego obiektu, a następnie odtwarza ją na światłoczułej matrycy. Odpowiednio zsynchronizowany kontroler wylicza dane o odległości (oś Z) oraz pozycji wzdłuż linii lasera (oś $X$ ), a następnie odnosi je do dwuwymiarowego układu współrzędnych.

Uzyskano 510 profili każdej z 6 badanych próbek. Do analizy wybrano co dziesiaty z tych profili, czyli po 40 profili zawierających po 1280 punktów pomiarowych. Dokładność pomiaru wynosiła $1 \mu \mathrm{m}$ w poziomie i $10 \mu \mathrm{m}$ w pionie. Dane dotyczące tych profili zostały zaimportowane do programu OmniSurf. Korzystając z tego programu obliczono amplitudowe (wysokościowe) parametry chropowatości $(R a, R c$ i $R t)$ i falistości $(W a, W c, W t)$ powierzchni

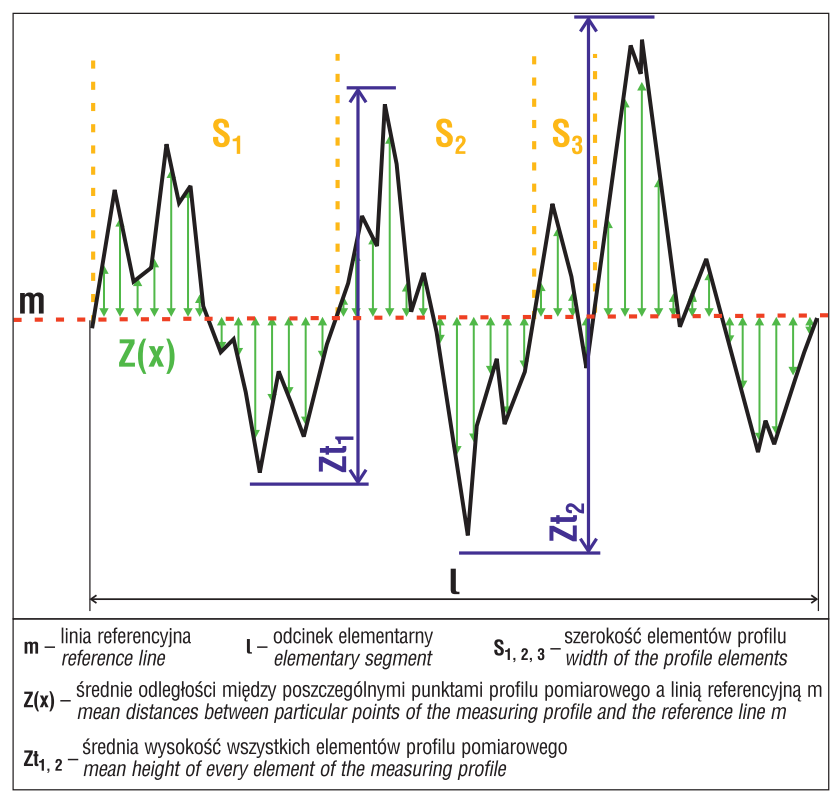

Ryc. 1. Graficzna prezentacja parametrów chropowatości i falistości

Fig. 1. Graphic presentation of the roughness and waviness parameters badanych skał, jak również parametry częstotliwościowe (odległościowe), określane jako Rsm i Wsm.

Do opisu morfologii powierzchni najczęściej są wykorzystywane parametry $\mathrm{Ra}$ i $\mathrm{Wa}$. Są one interpretowane jako średnie odległości między poszczególnymi punktami profilu pomiarowego $Z(x)$ wewnątrz odcinka elementarnego $l$ a linią referencyjną $m$, w stosunku do której mierzy się odchylenia profilu (ryc. 1). Parametry te obliczono ze wzoru [1]:

$$
R a, W a=\frac{1}{l} \int_{0}^{l}|Z(x)| d x
$$

Wskaźniki $R c$ i $W c$ są określane jako średnia wysokość wszystkich elementów profilu, rozumiana jako odległość od wgłębienia do wzniesienia (ryc. 1). Obliczono je zgodnie ze wzorem [2]:

$$
R c, W c=\frac{1}{m} \sum_{l=1}^{m} Z t_{i}
$$

Parametry Rt i Wt wyrażają sumę odległości między najwyższym i najniższym punktem wewnątrz odcinka elementarnego $Z t_{2}$ (ryc. 1).

Parametry Rsm i Wsm odpowiadają wartości średniej szerokości elementów profilu wewnątrz analizowanego odcinka $S_{i}$ (ryc. 1). Obliczono je wg wzoru [3]:

$$
R s m, W s m=\frac{1}{m} \sum_{i=1}^{m} X s_{i}
$$

\section{WYNIKI BADAŃ}

\section{Petrografia}

Bazalt Twilight to skała o barwie ciemnoszarej, charakteryzująca się strukturą porfirowo-afanitową oraz zbitą i nieznacznie kierunkową teksturą, wyrażającą się płaskorównoległym ułożeniem minerałów blaszkowych i płytkowych (ryc. 2A). W tle skalnym są zauważalne dość liczne pirokseny, amfibole i biotyty, zajmujące $43,9 \%$ obj. skały. Osiagają one wielkość do $4 \mathrm{~mm}$. Plagioklazy są znacznie mniejsze (do $2 \mathrm{~mm}$ ) i wypełniają 29,0\% obj. tego bazaltu. Obecne są również oliwiny o rozmiarach do ok. 0,3 mm, (9,4\% obj.). Pozostałą część skały (17,7\% obj.) stanowią składniki ciasta skalnego.

Różowożółty granit Sunny Desert cechuje się strukturą średniokrystaliczną i subhedralną oraz zbitą i bezładną teksturą (ryc. 2B). Składa się on ze skaleni alkalicznych i plagioklazów, których łączny udział osiaga ok. 65,2\% obj. Ich wielkość jest zróżnicowana i wynosi od ok. 1 do $8 \mathrm{~mm}$. Kwarc-o rozmiarach ziaren od ok. 0,5 do $5 \mathrm{~mm}$ - zajmuje $31,5 \%$ obj. skały. Pozostała jej część (3,3\% obj.) stanowią biotyt, muskowit i nieliczne minerały rudne.

Granit Imperial Red ma barwę czerwonoszara. Jego struktura jest nierównokrystaliczna, natomiast tekstura jest zbita i bezładna (ryc. 2C). Skała ta składa się ze skaleni, głównie potasowych, oraz mniej licznych plagioklazów. Ich łączny udział wynosi 57,0\% obj. Rozmiary ziaren skaleni wahają się od ok. 0,5 do $20 \mathrm{~mm}$. Kwarc - o wielkości ziaren ok. 1-12 mm - wypełnia 32,9\% obj. skały. Pozostałe składniki $(10,1 \%$ obj.) to biotyt i muskowit. 

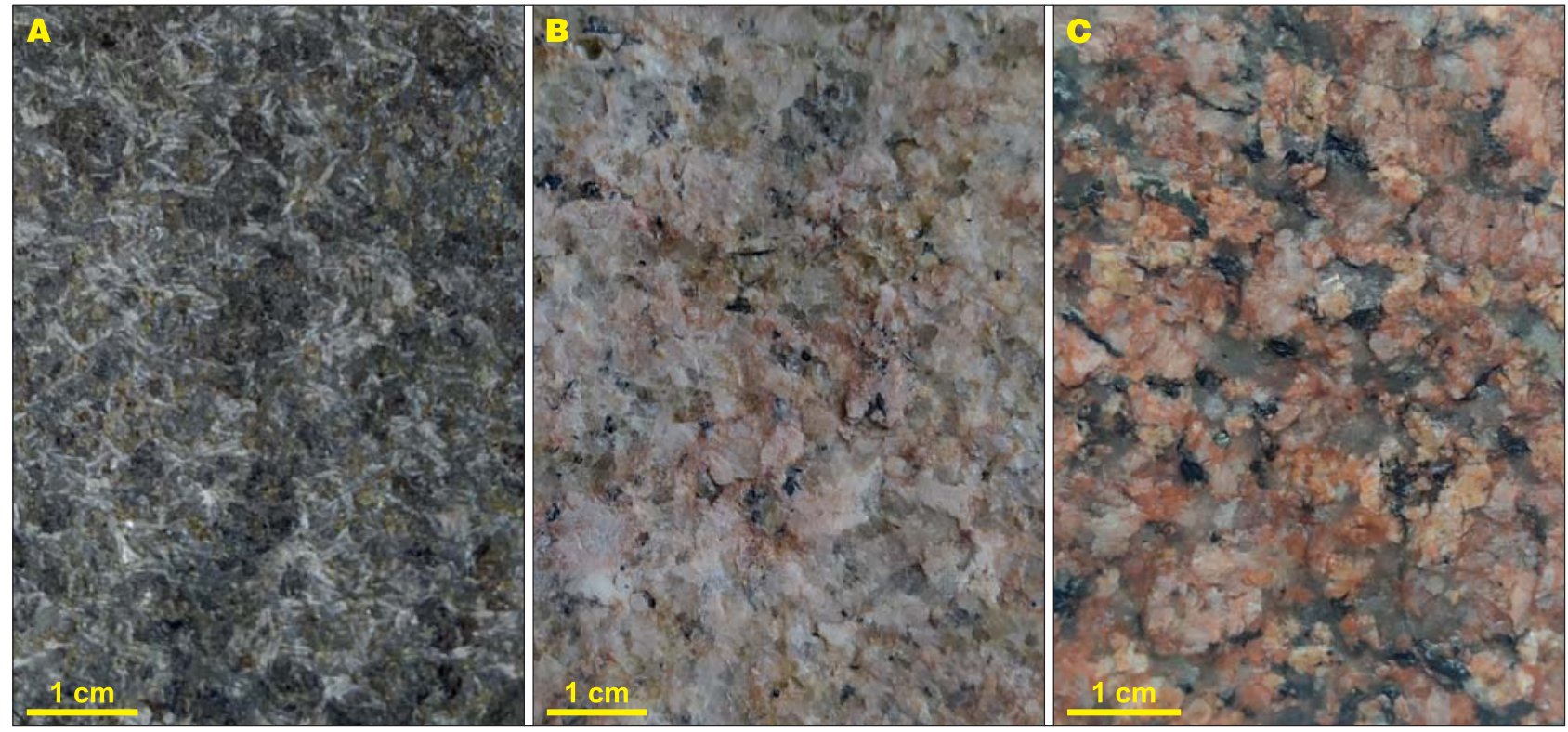

Ryc. 2. Płyty kamienne o powierzchni płomieniowanej: A - bazalt Twilight; $\mathbf{B}$ - granit Sunny Desert; $\mathbf{C}$ - granit Imperial Red Fig. 2. Surfaces of the flamed finish slabs: A - Twilight basalt; B - Sunny Desert granite; $\mathbf{C}$ - Imperial Red granite

\section{Chropowatość i falistość powierzchni}

Powierzchnia bazaltu Twilight o fakturze przecinanej w ocenie makroskopowej jest dość gładka, co wynika głównie z drobnego uziarnienia tej skały. Jednak pod mikroskopem stereoskopowym zaobserowano na niej liczne zagłębienia, aczkolwiek płytkie i płaskodenne. Powstały one głównie w miejscach występowania ziaren piroksenów, amfiboli i biotytu, ułożonych płaskorównolegle w stosunku do powierzchni próbki (ryc. 3-A1 - patrz str. 135). Tylko w nielicznych $\mathrm{z}$ tych ziaren, zorientowanych ukośnie, utworzyły się głębsze ubytki. W oliwinach, skaleniach i składnikach tła skalnego ubytków jest mniej, co stwarza pozorne wrażenie, że ziarna tych minerałów mają relief wypukły. Wnioski z obserwacji makro- i mikroskopowych zostały potwierdzone przez wyniki pomiarów mikrogeometrycznych, wedle których powierzchnia bazaltu Twilight o fakturze przecinanej cechuje się najniższymi wartościami wszystkich parametrów chropowatości i falistości spośród analizowanych powierzchni skał, poza częstotliwościowym parametrem Wsm, który wynosi $4,12 \mathrm{~mm}$ (ryc. 4, tab. 1). Dość wysoka wartość tego parametru jest spowodowana grupowaniem się $\mathrm{w}$ bazalcie Twilight minerałów maficznych w zespoły złożone z kilku ziaren, w których powstają stosunkowo rozległe i płaskie zagłębienia. Pomiędzy zespołami minerałów maficznych występują ziarna skaleni, tworzące razem z oliwinami i ciastem skalnym rozległe równie i wypłaszczone wzniesienia.

Powierzchnia granitu Sunny Desert, jaka powstała po przecięciu skały piła, jest równa, ale dość szorstka, z widocznymi makroskopowo licznymi ubytkami (ryc. 3-A2). Na ich obecność wskazują także podwyższone wartości parametrów $R a$ i $R c$, mieszczące się odpowiednio w zakresach: 6,9-11,19 $\mu \mathrm{m}$ oraz 22,6-38,68 $\mu \mathrm{m}$ (ryc. 5). Zagłębienia na tej powierzchni są zazwyczaj wąskie i o stromych ściankach, a także głębokie, o czym świadczy wartość parametru $R t$

Tab. 1. Wartość parametrów chropowatości i falistości badanych płyt kamiennych Table 1. Roughness and waviness parameters of the slabs

\begin{tabular}{|l|c|c|c|c|c|c|}
\hline \multirow{2}{*}{$\begin{array}{l}\text { Parametr } \\
\text { Parameter }\end{array}$} & \multicolumn{2}{|c|}{$\begin{array}{c}\text { Bazalt Twilight } \\
\text { "Twilight” basalt }\end{array}$} & \multicolumn{2}{c|}{$\begin{array}{c}\text { Granit Sunny Desert } \\
\text { "Sunny Desert" granite }\end{array}$} & \multicolumn{2}{|c|}{$\begin{array}{c}\text { Granit Imperial Red } \\
\text { "Imperial Red" granite }\end{array}$} \\
\cline { 2 - 7 } & $\begin{array}{c}\text { Faktura } \\
\text { przecinana } \\
\text { Saw-finished }\end{array}$ & $\begin{array}{c}\text { Faktura } \\
\text { plomieniowana } \\
\text { Flame-finished }\end{array}$ & $\begin{array}{c}\text { Faktura } \\
\text { przecinana } \\
\text { Saw-finished }\end{array}$ & $\begin{array}{c}\text { Faktura } \\
\text { plomieniowana } \\
\text { Flame-finished }\end{array}$ & $\begin{array}{c}\text { Faktura } \\
\text { Frzecinana } \\
\text { Saw-finished }\end{array}$ & $\begin{array}{c}\text { Faktura } \\
\text { plomieniowana } \\
\text { Flame-finished }\end{array}$ \\
\hline$R a[\mu \mathrm{m}]$ & 5,91 & $9,15(+39 \%)$ & 8,25 & $12,58(+52 \%)$ & 9,9 & $10,43(+5 \%)$ \\
\hline$R c[\mu \mathrm{m}]$ & 20,31 & $31,58(+55 \%)$ & 29,06 & $44,95(+55 \%)$ & 34,17 & $36,34(+6 \%)$ \\
\hline$R t[\mu \mathrm{m}]$ & 63,19 & $93,56(+48 \%)$ & 102,18 & $191,29(+87 \%)$ & 98,19 & $122,37(+25 \%)$ \\
\hline$R s m[\mathrm{~mm}]$ & 0,4 & $0,50(+25 \%)$ & 0,52 & $0,60(+15 \%)$ & 0,58 & $0,54(-7 \%)$ \\
\hline$W a[\mu \mathrm{m}]$ & 8,81 & $64,78(+635 \%)$ & 19,95 & $108,46(+443 \%)$ & 42,04 & $120,15(+186 \%)$ \\
\hline$W c[\mu \mathrm{m}]$ & 30,39 & $205,23(+575 \%)$ & 82,75 & $353,74(+327 \%)$ & 147,28 & $374,66(+154 \%)$ \\
\hline$W t[\mu \mathrm{m}]$ & 73,63 & $376,43(+411 \%)$ & 195,53 & $676,86(+246 \%)$ & 319,14 & $633,72(+99 \%)$ \\
\hline$W s m[\mathrm{~mm}]$ & 4,12 & $9,16(+122 \%)$ & 4,02 & $9,27(+131 \%)$ & 4,94 & $12,93(+162 \%)$ \\
\hline
\end{tabular}

W nawiasie podano procentowy wzrost (+) lub zmniejszenie (-) wartości parametru obliczonego dla powierzchni płomieniowanej, w stosunku do obliczonego dla powierzchni przecinanej.

Figures in the brackets are expressed in percents and indicate an increase (+) or decrease (-) in the value of the parameter calculated for the flame-finished surface in relation to the saw-finished surface. 
(średnio 102,18 $\mu \mathrm{m}$ ) - najwyższa spośród wszystkich odnotowanych w badanych próbkach o fakturze przecinanej (tab. 1). Zagłębienia o takim kształcie powstały głównie w pionowo i ukośnie ułożonych pakietach łyszczykowych, które podczas cięcia uległy rozwarstwieniu lub złamaniu i zostały oderwane od powierzchni. Część tego rodzaju ubytków powstała w ziarnach mocniej zwietrzałych skaleni, których brzeżne fragmenty wykruszyły się wzdłuż płaszczyzn łupliwości.

Wartości parametrów falistości są wyższe od wartości parametrów chropowatości. Wartość wskaźnika $W a$ mieści się $\mathrm{w}$ przedziale od 11,95 do $60,93 \mu \mathrm{m}$, natomiast $W_{c}$ wynosi od 41,01 do 268,44 $\mu \mathrm{m}$ (ryc. 5). Z analizy wartości parametru $R t$ wynika, że zagłębienia występują lokalnie i nie wpływają na podwyższenie wartości parametru $W t$, który jest określany w większej skali pomiaru. Stosunkowo równokrystaliczna i zarazem średniokrystaliczna struktura granitu Sunny Desert wpłynęła na niską (najniższą wśród badanych skał) wartość parametru częstotliwościowego Wsm (średnia wynosi 4,02 mm).

W granicie Imperial Red na powierzchni przecięcia płyty powstały nieliczne, ale dość głębokie, ubytki o stromych ścianach. Dobrze je widać w skupieniach łyszczyków, ale występują także w najmniejszych kryształach skaleni lub w brzeżnych częściach ich większych ziaren, na kontaktach z kwarcem. W dużej części ziaren skaleni

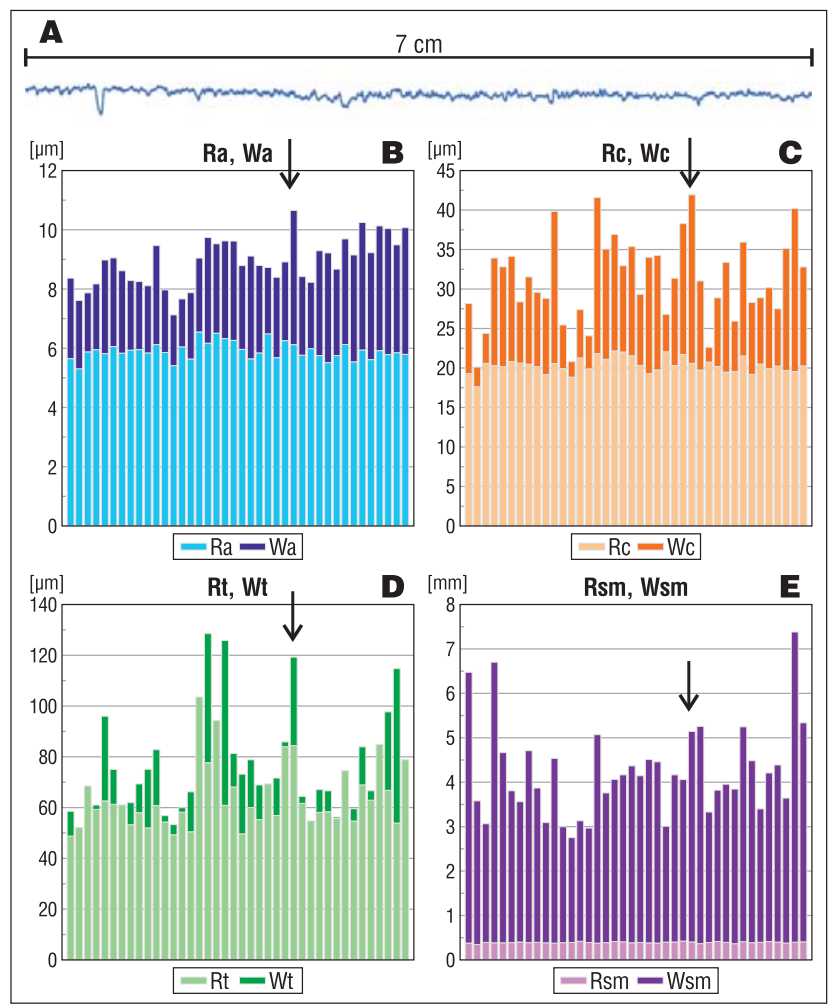

Ryc. 4. Wyniki pomiarów profilometrycznych wykonanych na powierzchni bazaltu Twilight o fakturze przecinanej: $\mathbf{A}$ - profil pomiarowy $\mathrm{nr} 215$; B-E - wykresy zmienności parametrów chropowatości: $R a, R c, R t$ i Rsm oraz falistości: $W a, W c, W t$ i $W s m$. Strzałką zaznaczono wartość parametru obliczoną dla profilu $\mathrm{nr} 215$ Fig. 4. Results of the profilometric measurements on the surface of the saw-finished Twilight basalt: A - measurement profile No. 215 ; B-E - graphs presenting variability of roughness parameter values $R a, R c, R t$ and $R s m$, and waviness parameter values $W a, W c$, $W t$ and $W s m$. Arrow indicates the parameter value calculated for profile No. 215 i kwarcu powstały odpryski o zróżnicowanych kształtach (ryc. 3-A3). W skaleniach formy odprysków są uzależnione od ułożenia płaszczyzn łupliwości w stosunku do powierzchni cięcia płyty i zwykle są dość płaskie, w morfologii powierzchni skały zaznaczają się pozytywnie. Ziarna kwarcu odspajają się wzdłuż powierzchni przełamu i zazwyczaj są nierówne oraz wklęsłe w stosunku do skaleni, a jednocześnie wyniesione nad blaszki łyszczyków. Zmienność kształtu powierzchni ziaren w tym granicie znalazła odbicie w wysokich wartościach parametrów chropowatości (ryc. 6). Niemal wszystkie $\mathrm{z}$ nich, $\mathrm{z}$ wyjątkiem $R$ t, są najwyższe spośród wyliczonych dla powierzchni badanych płyt kamiennych (tab. 1).

Średnia wartość wskaźnika Rt $(98,19 \mu \mathrm{m})$ granitu Imperial Red wskazuje, że drobne ubytki, jakie powstały na płaszczyźnie przecięcia tej skały, są nieco płytsze od stwierdzonych w granicie Sunny Desert. Powierzchnia próbki granitu Imperial Red jest niejednorodna morfologicznie, co jest związane ze zróżnicowanymi rozmiarami ziaren. Wyraża się to obecnością drobnych zagłębień w miejscach występowania łyszczyków oraz małych ziaren kwarcu, sąsiadujących z górującymi nad nimi zespołami kilku ziaren skaleni lub dużymi ich osobnikami o ząbkowanej, chropowatej powierzchni. W wielu miejscach są obecne większe ziarna kwarcu o wklęsłej, muszlowej powierzchni przełamu. Takie rozmieszczenie ziaren sprawiło, że granit

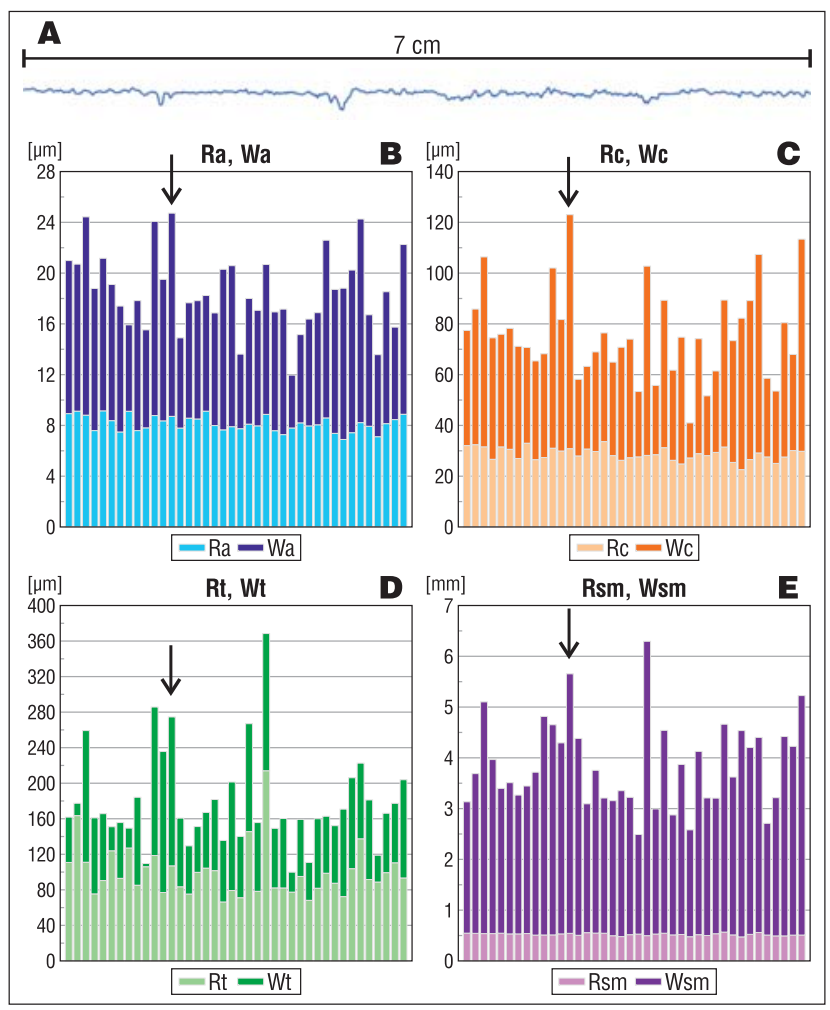

Ryc. 5. Wyniki pomiarów profilometrycznych wykonanych na powierzchni granitu Sunny Desert o fakturze przecinanej: A - profil pomiarowy $\mathrm{nr} 100$; B-E - wykresy zmienności parametrów chropowatości: $R a, R c, R t$ i Rsm oraz falistości: $W a, W c, W t$ i $W s m$. Strzałką zaznaczono wartość parametru obliczoną dla profilu $\mathrm{nr} 100$ Fig. 5. Results of the profilometric measurements on the surface of the saw-finished Sunny Desert granite: A - measurement profile No. 100; B-E - graphs presenting variability of roughness parameter values $R a, R c, R t$ and $R s m$, and waviness parameter values $W a, W c, W t$ and $W s m$. Arrow indicates the parameter value calculated for profile No. 100 
Imperial Red charakteryzuje się największymi wartościami wszystkich oznaczanych wskaźników falistości (tab. 1).

Termiczna obróbka badanych skał, nadająca im fakturę płomieniowana, spowodowała wzrost niemal wszystkich parametrów chropowatości i falistości w stosunku do charakterystycznych dla powierzchni przeciętej.

Wartość parametru $R a$, charakteryzującego płomieniowaną powierzchnię bazaltu Twilight, wzrosła o 39\%. Wskaźnik Rt zwiększył się nieznacznie więcej, gdyż o 48\%, a wartość parametru $R c-$ o 55\% (tab. 1, ryc. 7). Zbliżone zmiany wartości tych parametrów wskazują, że ziarna minerałów badanych skał w podobny sposób poddawały się zarówno przecinaniu, jak i obróbce termicznej, jednak w tym drugim przypadku nasiliły się w nich objawy destrukcji. Szczególnie wyraźnie jest to widoczne w amfibolach, piroksenach i biotycie. Przy czym wartość Rsm wzrosła nieznacznie, gdyż o $25 \%$, co świadczy o tym, że pogłębiające się ubytki tylko nieznacznie zwiększały swoją powierzchnię. Dość dobrze zachowały się oliwiny, które na powierzchni płyty wyróżniają się reliefem dodatnim, ale wskutek działania wysokiej temperatury ich górna powierzchnia zaokragliła się (ryc. 3-B1). Ziarna plagioklazów nadal występują $\mathrm{w}$ formie płaskich wzniesień, lecz pojawiło się w nich znacznie więcej drobnych odprysków.

Płomieniowanie przyczyniło się do znacznego wzrostu wartości parametrów falistości powierzchni bazaltu Twilight. Najwięcej wzrosła wartość parametru $W a$ - aż o 635\%.

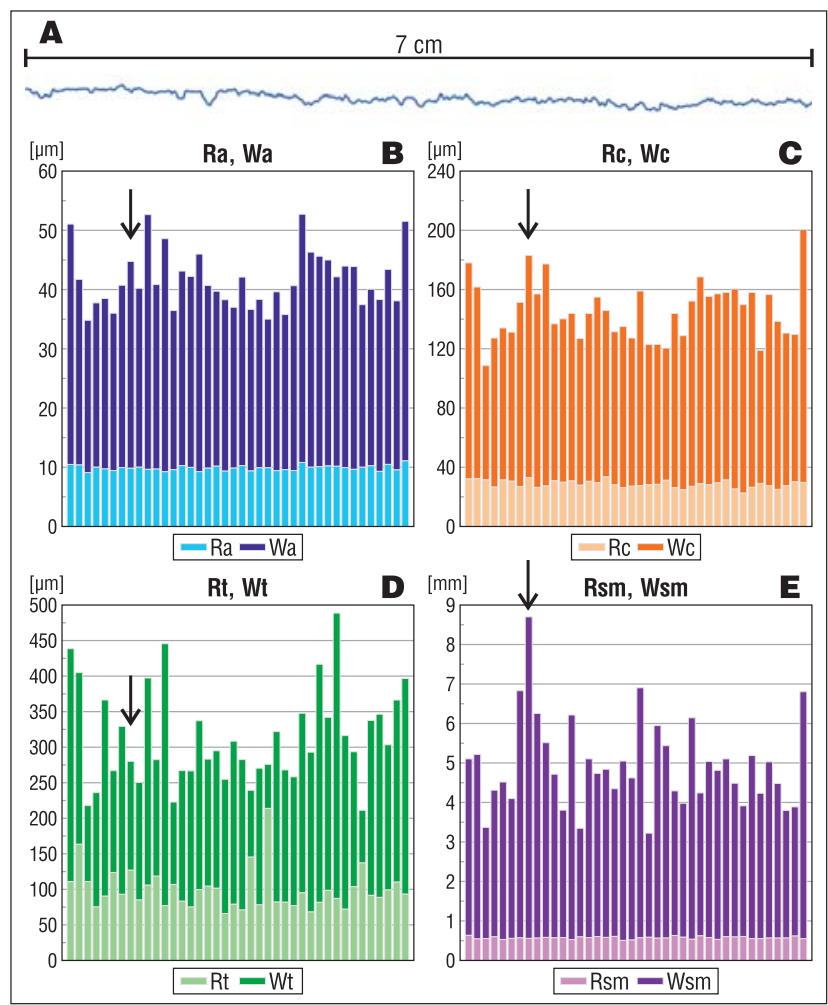

Ryc. 6. Wyniki pomiarów profilometrycznych wykonanych na powierzchni granitu Imperial Red o fakturze przecinanej: A - profil pomiarowy nr 60; $\mathbf{B}-\mathbf{E}$ : wykresy zmienności parametrów chropowatości: Ra, Rc, Rt i Rsm oraz falistości: Wa, Wc, Wt i Wsm. Strzałką zaznaczono wartość parametru obliczoną dla profilu nr 60

Fig. 6. Results of the profilometric measurements on the surface of the saw-finished Imperial Red granite: $\mathbf{A}$ - measurement profile No. 60; B-E - graphs presenting variability of roughness parameter values $R a, R c, R t$ and $R s m$, and waviness parameter values $W a, W c, W t$ and $W s m$. Arrow indicates the parameter value calculated for profile No. 60
Podobnie zwiększyła się wartość wskaźnika $W c$, bowiem o $575 \%$, a tylko nieznacznie mniej, tj. o $411 \%$, parametru $W t$ (tab. 1, ryc. 7). Takie wyniki wskazują, że proces płomieniowania spowodował odspajanie się dużych fragmentów ziaren krystalicznych o znacznej grubości. Destrukcja poszczególnych ziaren minerałów dokonywała się indywidualnie, proporcjonalnie do ich właściwości sprężystych oraz odporności termicznej, warunkowanej, jak to wcześniej wspomniano, wartością współczynnika cieplnej rozszerzalności objętościowej. W związku $\mathrm{z}$ tym tylko nieznacznie zwiększyły się powierzchnie powstałych ubytków, o czym świadczy stosunkowo niewielki wzrost wartości parametru Wsm, wynoszący 122\%.

Wartość parametrów chropowatości i falistości powierzchni granitu Sunny Desert po obróbce termicznej była większa niż tych samych parametrów płomieniowanej powierzchni bazaltu, mimo że zmiany powstałe w reliefie obu płyt były podobnej wielkości (tab. 1). Wartość wskaźnika $R a$ zwiększyła się o $52 \%$, a wskaźnika $R c$ o $55 \%$. Nieco więcej (o 87\%) wzrosła wartość parametru Rt (tab. 1, ryc. 8). Zmiany te są głównie efektem powstania pod wpływem płomieniowania nieco głębszych ubytków w łyszczykach i zwietrzałych skaleniach, od wytworzonych w tych minerałach w wyniku przecięcia skały. W kwarcu nie stwierdzono istotnych zmian, w tym pogłębienia drobnych odprysków. Niewielki wzrost wartości częstotliwościowego parametru Rsm (zaledwie o 15\%) wskazuje, że

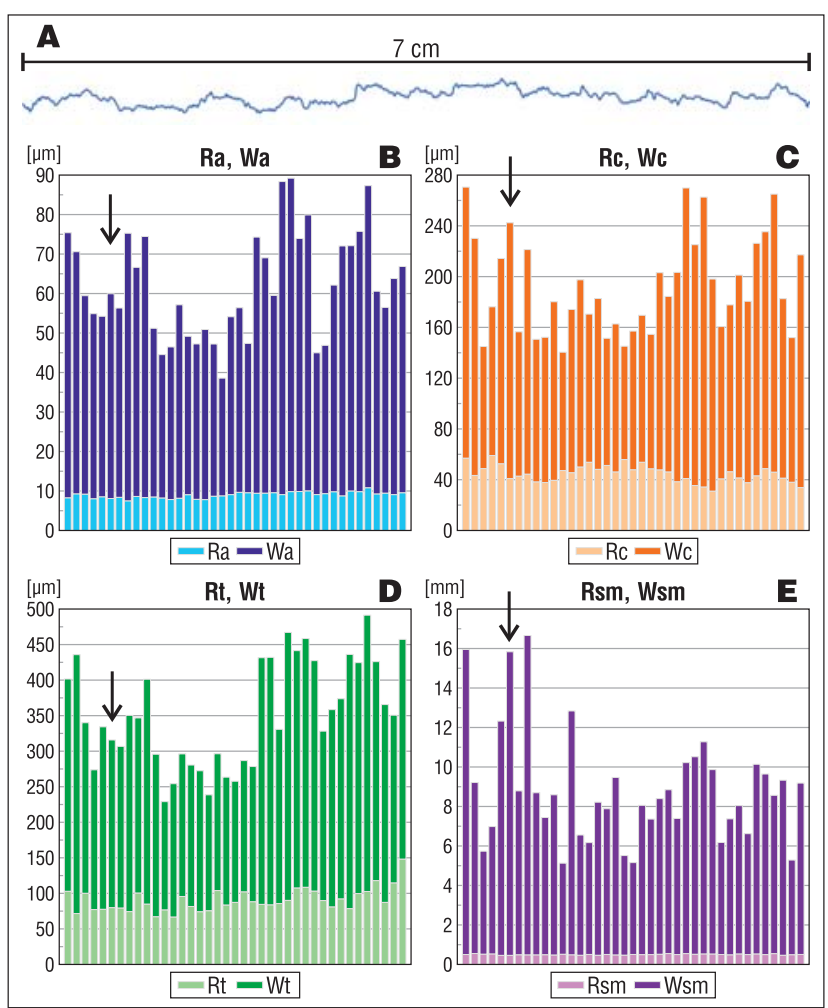

Ryc. 7. Wyniki pomiarów profilometrycznych wykonanych na powierzchni bazaltu Twilight o fakturze płomieniowanej: $\mathbf{A}$-profil pomiarowy $\mathrm{nr} 40$; $\mathbf{B}-\mathbf{E}$ - wykresy zmienności parametrów chropowatości: Ra, Rc, Rt i Rsm oraz falistości: $W a, W_{c}, W t$ i $W_{s m}$. Strzałką zaznaczono wartość parametru obliczoną dla profilu nr 40

Fig. 7. Results of the profilometric measurements on the surface of the flame-finished Twilight basalt: A-measurement profile No. 40; $\mathbf{B}-\mathbf{E}$ - graphs presenting variability of roughness parameter values $R a, R c, R t$ and $R s m$, and waviness parameter values $W a, W c, W t$ and $W_{s m}$. Arrow indicates the parameter value calculated for profile No. 40 


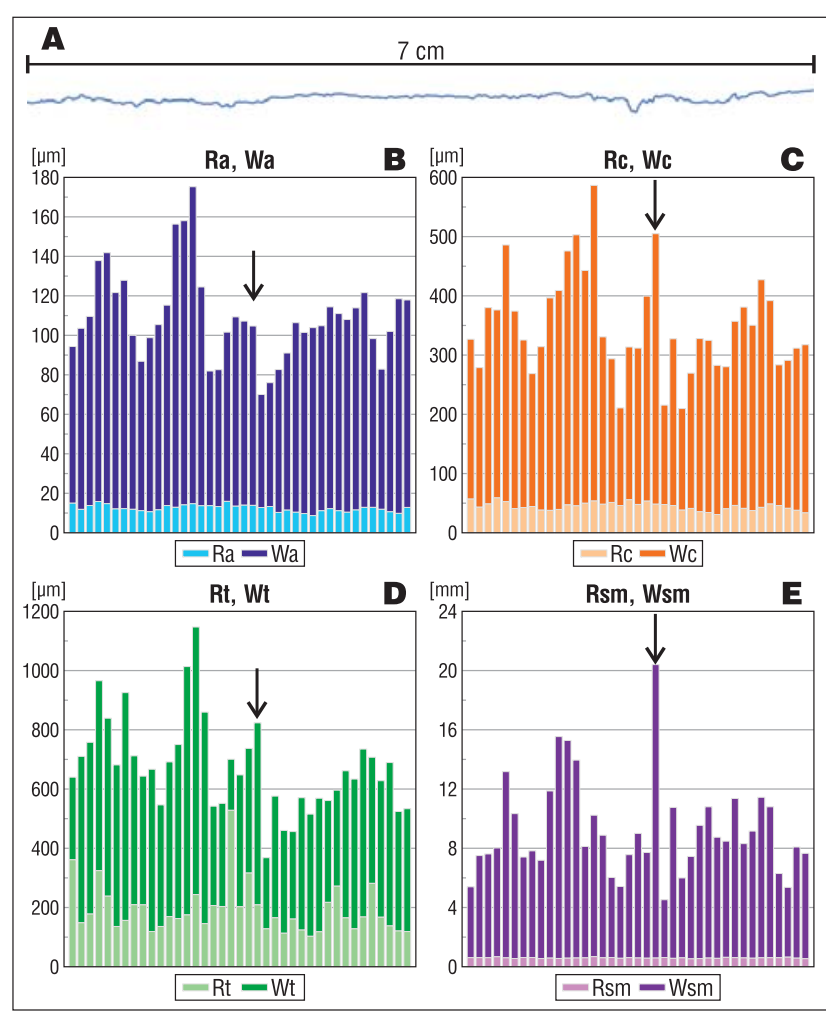

Ryc. 8. Wyniki pomiarów profilometrycznych wykonanych na powierzchni granitu Sunny Desert o fakturze płomieniowanej: A-profil pomiarowy $\mathrm{nr} 170 ; \mathbf{B}-\mathbf{E}$ - wykresy zmienności parametrów chropowatości: $R a, R c, R t$ i $R s m$ oraz falistości: $W a, W c, W t$ i $W s m$. Strzałka zaznaczono wartość parametru obliczona dla profilu $\mathrm{nr} 170$ Fig. 8. Results of the profilometric measurements on the surface of the flame-finished Sunny Desert granite: $\mathbf{A}$ - measurement profile No. 170; B-E - graphs presenting variability of roughness parameter values $R a, R c, R t$ and $R s m$, and waviness parameter values $W a, W c$, $W t$ and $W s m$. Arrow indicates the parameter value calculated for profile No. 170

głębokie ubytki, rejestrowane na poszczególnych odcinkach profilu chropowatości, niemal w ogóle nie zwiększały swojej powierzchni w stosunku do tworzących się na powierzchni przecinanej. Zarówno w granicie Sunny Desert, jak i w bazalcie Twilight pod wpływem płomieniowania nastąpiła istotna zmiana parametrów falistości. Wskaźnik $W a$ wzrósł o $443 \%$, a $W c$ o $327 \%$. Odnotowano natomiast nieco mniejszy wzrost wartości parametru $W t$ o $246 \%$ (tab. 1). Zauważono, że zmiany te wiążą się z powstaniem dość głębokich odprysków na powierzchni skały, obejmujących całe ziarna kwarcu (ryc. 3-B2). W mniejszym stopniu zjawisko to dotyczyło pozostałych minerałów, w których powierzchnie ubytków zwiększyły się nieznacznie, co spowodowało wzrost wartości parametru Wsm o $131 \%$.

Obróbka termiczna płyty granitu Imperial Red nie spowodowała istotnych zmian w morfologii minerałów odsłaniających się na jej podgrzewanej powierzchni. Wskazują na to wartości parametrów chropowatości płomieniowanej tafli tej skały, które są niemal takie same jak wartości parametrów charakteryzujące powierzchnię o fakturze przecinanej. Wartość wskaźników $R a$ i $R c$ zwiększyła się (odpowiednio) tylko o 5 i 6\%, a $R t$ o $25 \%$ (tab. 1, ryc. 9). Natomiast wartość parametru Rsm nawet nieznacznie się zmniejszyła (o 7\%). Warto zwrócić uwagę na to, że wszyst-

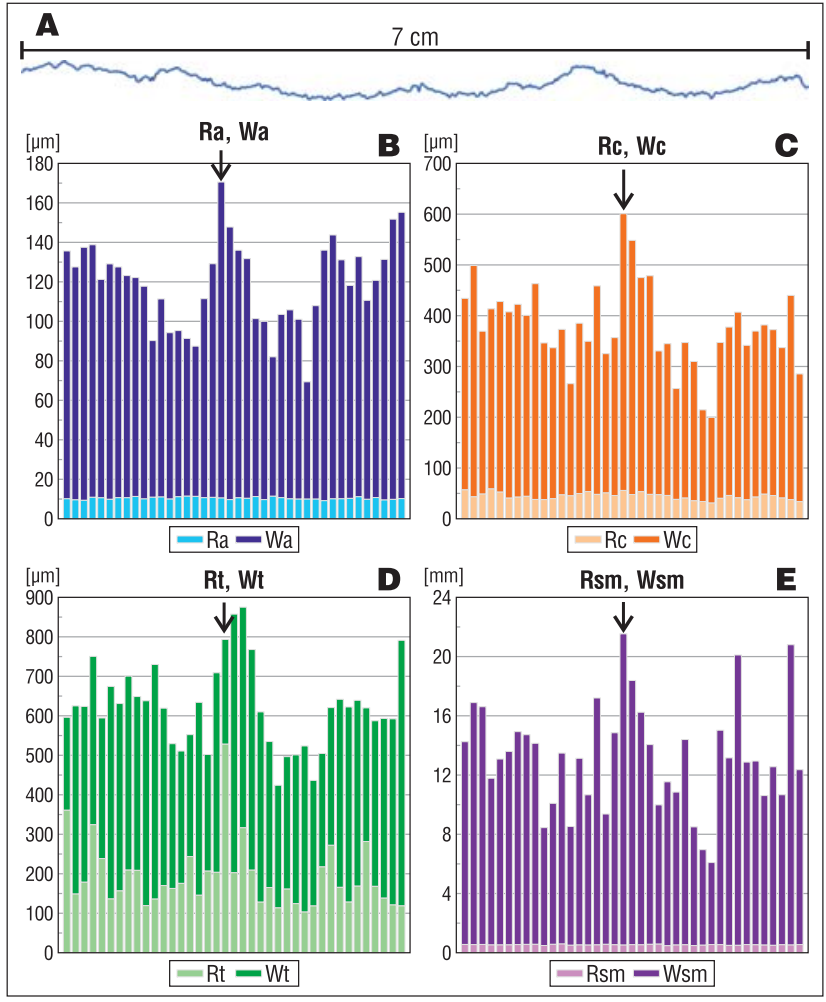

Ryc. 9. Wyniki pomiarów profilometrycznych wykonanych na powierzchni granitu Imperial Red o fakturze płomieniowanej: $\mathbf{A}$ - profil pomiarowy nr 150; B-E - wykresy zmienności parametrów chropowatości: $R a, R c, R t$ i $R s m$ oraz falistości: $W a, W c, W t$ i $W s m$. Strzałką zaznaczono wartość parametru obliczoną dla profilu $\mathrm{nr} 150$ Fig. 9. Results of the profilometric measurements on the surface of the flame-finished Imperial Red granite: $\mathbf{A}$ - measurement profile No. 150 ; B-E - graphs presenting variability of roughness parameter values $R a, R c, R t$ and $R s m$, and waviness parameter values $W a, W c, W t$ and $W s m$. Arrow indicates the parameter value calculated for profile No. 150

kie wartości parametrów charakteryzujących płomieniowaną powierzchnię granitu Imperial Red są niższe od właściwych dla granitu Sunny Desert o takiej samej fakturze, w którym płomieniowanie spowodowało istotne pogłębienie ubytków i zmianę profilu chropowatości. Po nadaniu powierzchni granitu Imperial Red faktury płomieniowanej wartości parametrów jej falistości zwiększyły się, choć procentowo nie tak znacznie jak u dwóch pozostałych skał poddanych analizie. Parametr $W a$ osiagnął $120,15 \mu \mathrm{m}$, czyli zwiększył się o 186\%, a wskaźnik $W_{c}-$ $374,66 \mu \mathrm{m}$, co oznacza wzrost o $154 \%$ (tab. 1). Odnotowano także podwyższenie wartości częstotliwościowego parametru $W_{s m}$ - do 12,93 mm (wzrost o 162\%). Wskaźniki falistości granitu Imperial Red mają największe wartości wśród badanych skał. W wyniku płomieniowania najmniej wzrosła (o 99\%) wartość parametru $W t$ powierzchni tej skały (do 633,72 $\mu \mathrm{m}$ ) i jest ona nieco niższa od wyliczonej dla granitu Sunny Desert.

Znaczna falistość płomieniowanej powierzchni granitu Imperial Red wynika przede wszystkim z obecności pokaźnych, nieregularnych zagłębień, powstałych w ziarnach kwarcu o różnej wielkości. Sąsiadują one z ziarnami skaleni, które odznaczają się dodatnim reliefem, ale w odróżnieniu od obserwowanych na powierzchni przecinanej są zaokraglone (ryc. 3-B3). Ubytki powstałe w skupieniach 
biotytu zaznaczają się w profilu falistości jedynie jako wąskie, ujemne anomalie.

\section{PODSUMOWANIE}

Na przykładzie wyników badań trzech skał magmowych o zróżnicowanej litologii wykazano, że wartość wskaźników chropowatości i falistości powierzchni wykonanych z nich płyt kamiennych jest ściśle uzależniona od właściwości fizycznych minerałów skałotórczych tych skał oraz od sposobu obrobienia tafli płyt. Na podatność skały na obróbkę mechaniczną składają się: zwięzłość, wynikająca $z$ naturalnej twardości jej minerałów i stopnia ich zwietrzenia, a także sposób podzielności minerałów, rozumiany jako zdolność do pękania wzdłuż płaszczyzn łupliwości lub powierzchni przełamu. Kluczową rolę w kształtowaniu płomieniowanej faktury skał odgrywa wartość współczynnika cieplnej rozszerzalności objętościowej ich minerałów. Decyduje ona o sile naprężeń powstających na granicach minerałów sąsiadujących ze sobą w skale i powodujących ich spękanie (Cooper, Simmons, 1977). Na kształt powierzchni wytwarzanych poprzez cięcie piłą lub płomieniowanie wpływa także rozmiar ziaren krystalicznych w skale oraz kierunek ich ułożenia względem powierzchni poddanej obróbce.

Średniokrystaliczny granit Sunny Desert o bezładnym ułożeniu minerałów charakteryzował się największą chropowatością wśród rozpatrywanych powierzchni płomieniowanych. Natomiast nierównokrystaliczny granit Imperial Red, również o bezładnej teksturze, miał największą chropowatość w grupie trzech analizowanych powierzchni płyt o fakturze przecinanej. Przy czym falistość powierzchni obu tych skał była podobna. Drobnokrystaliczny bazalt Twilight o nieznacznie kierunkowym ułożeniu minerałów, miał najniższe wartości wszystkich analizowanych parametrów.

Powierzchnie trzech badanych płyt skalnych o fakturze płomieniowanej miały wyraźnie większą chropowatość oraz kilkakrotnie większą falistość od powierzchni uzyskanych poprzez cięcie. Wyjątek stanowił granit Imperial Red, w którym pod wpływem płomieniowania nie nastąpiło istotne pogłębienie ubytków, co przełożyło się na znikomy wzrost wartości parametrów chropowatości i umiarkowane zwiększenie wskaźników falistości.
Metoda profilometrii laserowej jest narzędziem przydatnym do precyzyjnego parametryzowania rodzaju i wielkości nierówności na powierzchniach skał i z powodzeniem może być stosowana do oceny efektywności obróbki kamienia budowlanego. Ułatwia identyfikację powierzchniowych mikrodefektów lub nieciagłości teksturalnych na powierzchniach poddanych szlifowaniu lub polerowaniu. Umożliwia ocenę skuteczności obróbki płyt przeznaczonych do wykonania nawierzchni drogowych lub posadzek, zwłaszcza gdy wartość zmierzonych parametrów zostanie powiązana $\mathrm{z}$ antypoślizgowymi właściwościami powierzchni.

Praca została zrealizowana w AGH Akademii Górniczo-Hutniczej im. Stanisława Staszica w Krakowie, na Wydziale Geologii, Geofizyki i Ochrony Środowiska. Badania były finansowane ze środków Ministerstwa Nauki i Szkolnictwa Wyższego przeznaczonych na naukę.

\section{LITERATURA}

COOPER H.W., SIMMONS G. 1977 - The effect of cracks on the thermal expansion of rocks. Earth Planet. Sci. Lett., 36 (3): 404-412. HUOTARI T., KUKKONEN I. 2004 - Thermal expansion properties of rock: literature survey and estimation of thermal expansion coefficient for Olkiluoto Mica Gneiss. Working Report, Olkiluoto: 1-63.

KALINOWSKI Z. 2003 - Płomieniowanie - żywioł pracy. Świat Kamienia, 22: 52-56.

NINGAPPA C., SANNAPPA J., KARUNAKARA N. 2008 - Study on radionuclides in granite quarries of Bangalore rural district, Karnataka, India. Radiation Protection Dosimetry, 131 (4): 495-502.

PN-58/M-04252. Struktura geometryczna powierzchni. Oznaczanie chropowatości, kierunkowości struktury i sposobu obróbki.

PN-89/M-04256/04. Struktura geometryczna powierzchni. Falistość powierzchni. Terminologia.

PN-EN ISO 1302:2004. Specyfikacje geometrii wyrobów (GPS). Oznaczanie struktury geometrycznej powierzchni w dokumentacji technicznej wyrobu.

PN-EN ISO 4287:1999. Specyfikacje geometrii wyrobów. Struktura geometryczna powierzchni: metoda profilowa. Terminy, definicje i parametry struktury geometrycznej powierzchni.

ROBERTSON E.C. 1988 - Thermal properties of rock. United States Department of the Interior Geol. Survey, Open File Rept., 88-441: $1-106$.

TANTUSSI G., LANZETTA M. 2007 - Analyses of stone surfaces by optical methods. [W:] AI Te. M. 2007, $8^{\text {th }}$ Conference of the Italian Association of Mechanical Technology: 100-128.

ZHAO J.L., QIU J.S., LIU L., WANG R.Q. 2015 - Geochronological, geochemical and $\mathrm{Nd}-\mathrm{Hf}$ isotopic constraints on the petrogenesis of Late Cretaceous A-type granites from southeastern coast of Fujian Province, South China. J. Asian Sci., 105: 338-359.

Praca wpłynęła do redakcji 12.12.2020 r. Akceptowano do druku 19.01.2021 r. 
Profilometria laserowa $w$ badaniach kamiennych elementów budowlanych poddanych obróbce mechanicznej i termicznej (patrz str. 120)

Application of laser profilometry in the investigation of mechanically and thermally treated stone elements (see p. 120)
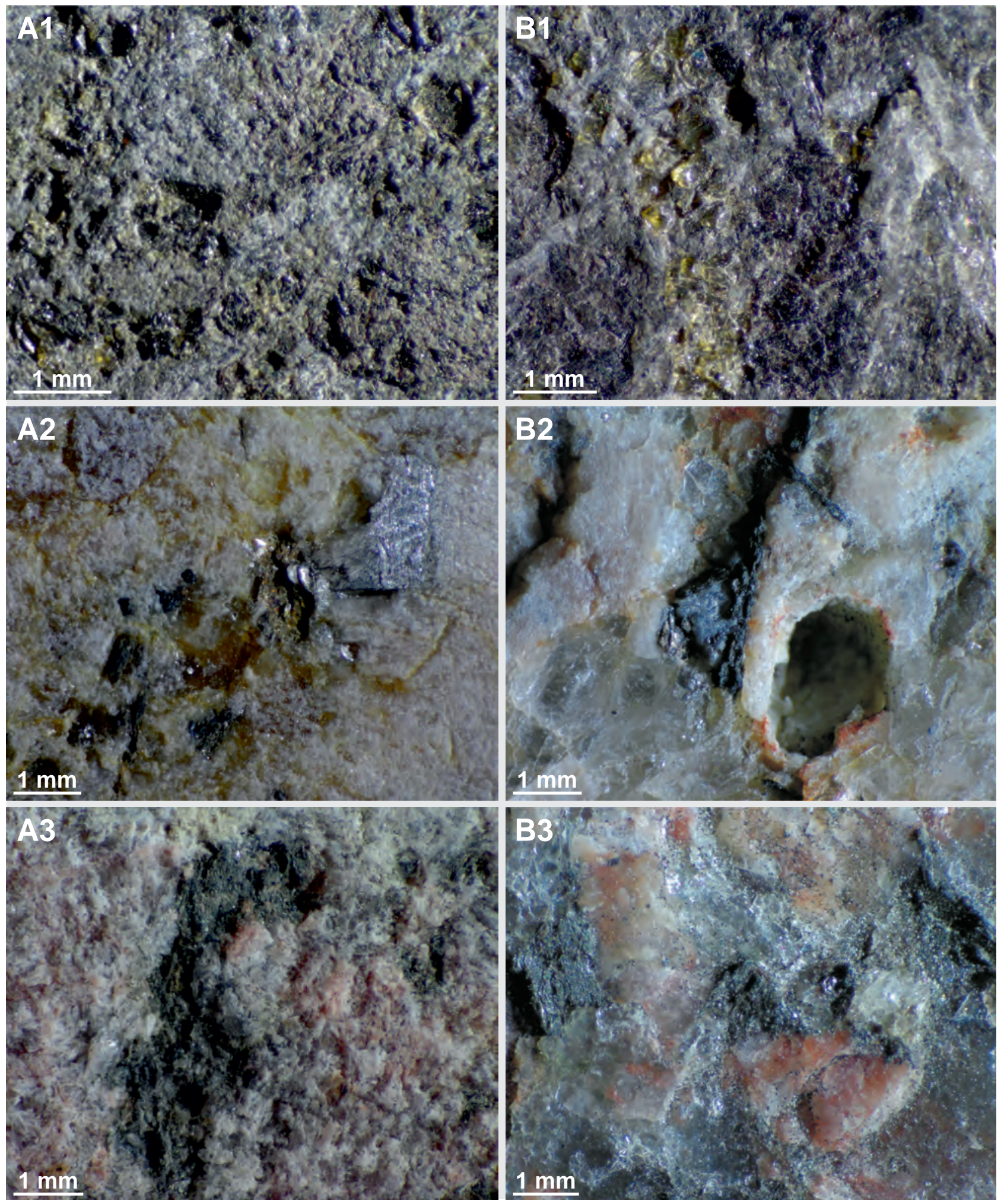

Ryc. 3. Powiększone fragmenty powierzchni badanych płyt kamiennych: A - faktura przecinana (1 - bazalt Twilight, 2 - granit Sunny Desert, 3 - granit Imperial Red); B - faktura płomieniowana (1 - bazalt Twilight, 2 - granit Sunny Desert, 3 - granit Imperial Red)

Fig. 3. Enlarged parts of stone slabs surface: A - saw-finished (1 - Twilight basalt, 2 - Sunny Desert granite, 3 - Imperial Red granite); B - flame-finished (1 - Twilight basalt, 2 - Sunny Desert granite, 3 - Imperial Red granite) 